(c) American Dairy Science Association, 2004.

\title{
Effect of Clinical Mastitis on the Lactation Curve: A Mixed Model Estimation Using Daily Milk Weights
}

\author{
D. J. Wilson, R. N. González, J. Hertl, H. F. Schulte, \\ G. J. Bennett, Y. H. Schukken, and Y. T. Gröhn \\ Department of Population Medicine and Diagnostic Sciences, \\ Cornell University, Ithaca, NY 14850
}

\begin{abstract}
The objective of this study was to estimate the milk production losses associated with clinical mastitis using mixed linear models and correlation structures that have not been available previously. Data used included computer-recorded daily milk yields and detailed and accurate recordings of clinical mastitis cases. Two commercial Holstein dairy farms in New York State participated in the study, one with 650 lactating cows and another that began the study with 830 lactating cows and increased to 1120 cows by the end of the study. Cows on both farms were housed in free stall barns and milked 3 times daily in milking parlors. Electrical conductivity was used as a diagnostic aid for clinical mastitis on both farms. Date of clinical onset was recorded for every episode of clinical mastitis as well as for 8 other diseases defined using standardized case definitions (dystocia, milk fever, retained placenta, metritis, ketosis, displaced abomasum, lameness, and cystic ovarian disease) during the study period of October 1, 1999 to July 31, 2001. The mixed linear model for explaining variation in the outcome variable daily milk yield relative to non-mastitic herdmates found the terms for all 9 diseases studied, including clinical mastitis, significant. The model with an autoregressive correlation structure was preferred based on $-2 * \log$ likelihood, Akaike's information criterion, and Bayesian information criterion as well as savings in degrees of freedom. Separate analyses were run for first lactation cows and for second-plus lactation cows because their lactation curves were shaped differently. Adjusting for the effects of the other 8 diseases, milk production loss from clinical mastitis during the whole lactation was estimated as approximately $598 \mathrm{~kg}$ for second-plus lactation cows. However, cows that contracted mastitis had a daily production advantage of $2.6 \mathrm{~kg}$ over their herdmates until they contracted the disease. When
\end{abstract}

Received October 31, 2003.

Accepted March 8, 2004.

Corresponding author: D. Wilson; e-mail: djw11@cornell.edu. compared with this potentially higher milk production, the total loss from clinical mastitis was estimated as $1181 \mathrm{~kg}$.

(Key words: bovine mastitis, milk loss, daily milk, statistical model)

Abbreviation key: $-\mathbf{2 L L}=-2 * \log$ likelihood, AIC $=$ Akaike's information criterion, $\mathbf{A R ( 1 )}=$ autoregressive (1), BIC = Bayesian information criterion, $\mathbf{C N S}=$ coagulase-negative staphylococci.

\section{INTRODUCTION}

Profitable milk production in the US has become highly dependent on intensive methods of husbandry, large herd sizes, and group handling of dairy cattle. Diseases are very important production-limiting factors, of which bovine mastitis is an excellent example. Losses caused by mastitis have been attributed mainly to decreased milk production from subclinical mastitis (Raubertas and Shook, 1982; Lucey and Rowlands, 1983; Allore and Erb, 1998; Bartlett et al., 1990); mastitis control programs are increasingly being used to reduce such losses. In recent years, the proportion of clinical mastitis cases caused by environmental bacteria has increased in well-managed herds (Bramley and Dodd, 1984; Erskine et al., 1988; Hogan et al., 1989; Bramley, 1990; Gonzalez et al., 1990; DeGraves and Fetrow, 1993). In these well-managed herds with excellent control of subclinical mastitis, increased attention should be paid to clinical mastitis. Costs associated with clinical mastitis include lower production, discarded milk because of antibiotic therapy, labor, veterinary costs and treatments, and culling or death (Cobo-Abreu et al., 1979; Bartlett et al., 1991).

There have been 3 primary statistical approaches in the investigation of the effect of disease on milk production: comparison of means (Raubertas and Shook, 1982), fitting to curves (Lucey et al., 1986), and time series (Deluyker et al., 1990). These approaches to estimation of milk losses have important analytical and data quality limitations. The first method (Dohoo and Martin, 1984) compares the average lactation pro- 
duction from cows with a specific disease to cohorts without disease using a multiple linear regression model. A potential bias in these estimates is that many dairy cattle diseases are more commonly contracted by cows with above average milk production, and thus disease-free cows are somewhat below average in milk production at the time of disease onset. Therefore, comparison of raw production data without accounting for production potential tends to mask the full effect of disease. The second method uses maximum-likelihood techniques to model each cow's production (Lucey and Rowlands, 1983). This method fits the diseased cow's milk yield to an incomplete gamma equation (Wood, 1967, 1977). Although this model was able to identify some transient milk losses associated with disease (because all milk weights were used to fit the model), the net impact of disease was forced to zero. Furthermore, Wood's equation is not accurate at describing the initial shape of the lactation curve (Dhanoa and LeDu, 1982). The third method involves the use of prior milk production to predict future production (DeLuyker et al., 1990, 1991). Time-series analysis was used to forecast shortterm milk production. These time-series estimates were developed from non-diseased cows and then applied to cows with clinical disease diagnoses. Because of the gradual decrease in production from certain clinical diseases, the time-series approach is unable to detect the milk loss from these diseases. Also, the method does not consider the case in which there is a sudden drop in milk production in all cows, for example in the case of a ration change or different weather conditions.

Y. T Gröhn previously tested general linear mixed models theory to model milk production and found it to be an appropriate method when estimating the effect of disease on milk production (Detilleux et al., 1994, 1997). A mixed model for repeated measurements (autoregression) was designed to model the correlation structure among monthly (or daily) milk yields in the same cow in the same herd. In those studies, we used mixed linear models applying an autocorrelation error to measure the loss of milk production following ketosis in Finnish Ayrshires (Detilleux et al., 1994). Although ketotic cows produced more milk over the entire lactation than did their non-ketotic herdmates, we found that they experienced a drop in milk production immediately following ketosis. The advantage of using repeated daily milk yields is that changes in milk production caused by disease episodes can be easily seen, both before and after diagnosis.

The objective of this study was to estimate the milk production losses associated with clinical mastitis using mixed linear models and correlation structures that have not been available previously. Data used included computer-recorded daily milk yields, detailed and accu- rate recording of clinical mastitis cases, and recording of cases of 8 other diseases.

\section{MATERIALS AND METHODS}

Data were collected from 2 large commercial Holstein dairy herds in New York State. Farm A milked 650 lactating cows housed in free stall barns bedded with paper sludge, shredded dry paper, or kiln-dried sawdust. Manure was scraped from alleys daily. Non-lactating cows were moved to a loose housing maternity pen bedded with straw when they were close to calving. New bedding was added to the cow housing areas every $3 \mathrm{~d}$. For the 1st wk of lactation, cows were housed in a large pen with a sand and sawdust combination for bedding, which was cleaned out weekly. Next to this pen, there was a 60 -stall free stall facility where animals were then moved and kept until 30 DIM.

Cows were milked in a double-12 parallel parlor 3 times a day. Predip with $0.5 \%$ titratable iodine teat dip was applied by mechanical sprayers. Following $30 \mathrm{~s}$ of minimum contact time, teats were dried off with cloth towels (one for each cow), which were laundered and dried between milkings. Milk meters recorded individual cow milk production, which was stored in a computerized database (S.A.E. Afikim, Kibbutz Afikim, Israel). Following automatic takeoff, teats were sprayed with the same $0.5 \%$ iodine teat dip after milking.

Clinical mastitis was detected in 1 of 4 ways: 1) by palpation of hot, hard, or swollen quarters during drying of teats in preparation for milking; 2) by appearance of abnormal milk after udder preparation; 3) by udder palpation and milk observation for cows with a milk electrical conductivity increase of $>15 \%$ relative to the previous $7 \mathrm{~d}$ that also had a milk production decrease; and 4) by examining the udder and milk of cows with a milk production decrease $>15 \%$ between subsequent milkings (regardless of electrical conductivity). At the beginning of the study, cows detected with clinical mastitis were moved into a hospital pen for mastitic cows, where they were administered oxytocin and were milked 4 times daily. Approximately 2 mo into the study, the treatment protocol was changed, and from then on cows with clinical mastitis were only milked 2 times per day. Amoxicillin trihydrate (Amoximast, Pfizer Animal Health, Groton, CT) was administered intramammarily for 3 consecutive milkings to cows with clinical mastitis that did not have signs of systemic disease. Cows with severe quarter swelling, rectal temperature $>39.7^{\circ} \mathrm{C}$, anorexia, or depression along with clinical mastitis were administered i.v. dextrose, calcium, sulfadimethoxine, and hypertonic saline, but were not necessarily treated with intramammary antibiotics according to the judgment of the attending herd- 
sperson. All cows were treated at the beginning of the nonlactating period with a commercial preparation of penicillin $\mathrm{G}$ (procaine) and dihydrostreptomycin sulfate (Quartermaster, Pfizer Animal Health).

As a separate study, for all cows with $\mathrm{SCC}<1,000,000 /$ $\mathrm{mL}$ at each of the last 3 monthly DHIA tests before drying off, one-half were administered a coliform mastitis bacterin according to label directions, and one-half were unvaccinated controls.

All groups of cows were fed a balanced TMR via feed alleys in free stall housing with headlocks, which allowed examination and administration of treatments. All lactating cows were administered subcutaneous recombinant bST (Posilac, Monsanto, St. Louis, MO) every 2 wk from approximately 70 DIM until 2 wk before the end of lactation. Cows were observed particularly closely in a smaller group during the first $30 \mathrm{~d}$ of lactation for any type of infection or ketosis. During the study, mean milk production per cow was $11,588 \mathrm{~kg} / \mathrm{yr}$ on a 305-d basis. Monthly mean bulk milk SCC was $225,000$ cells/mL (180,000 to 355,000$)$.

Farm B was milking 830 cows at the beginning of the study and expanded to 1120 lactating cows by the end of the study. Recently built covered free stall barns with concrete floors housed the lactating cows, divided by lactation, production, and reproductive status into 7 milking groups including 4 mature cow groups, a fresh cow group (up to $30 \mathrm{DIM}$ ), a first lactation cow group, and the treated cow group. Fresh sawdust bedding was added to freestalls twice per week. Dry cows were housed in an old free stall barn, divided into early dry period and late dry period groups. Ventilation, stall condition, and sawdust bedding were adequate in this older barn. Two weeks before her expected calving date, each cow was moved to a loose housing calving area bedded with chopped newspaper. Cows were returned to free stall housing $2 \mathrm{~d}$ after calving. First lactation cows were moved to a group of first lactation animals only for the remainder of their first lactation; mature cows entered the fresh cow group until they were 30 DIM. After the first $30 \mathrm{~d}$ of lactation, all mature cows went into one of the 4 mature cow groups. All lactating cows were administered subcutaneous recombinant bST every 2 wk from approximately 60 DIM until 2 wk before the end of lactation. Cows were milked 3 times a day in a double-24 herringbone parlor. Milking routine was the same as for Farm A except that the laundered cloth towels were not mechanically dried between milkings. This farm used the same individual cow milk production and electrical conductivity recording system as Farm A.

Clinical mastitis cases were identified by milkers when drying udders or by detecting changes in electrical conductivity, cows' walking (pedometer activity), or milk production compared with the average of the previous $7 \mathrm{~d}$. When 2 of the following conditions were satisfied, the cow went on mastitis alert status: electrical conductivity increase $>30 \%$, pedometer activity decrease $>40 \%$, milk production increase $<7 \%$ for cows 1 to 45 DIM, production decrease $>20 \%$ for cows 46 to 114 DIM, production decrease $>17 \%$ for cows 115 to 199 DIM, and production decrease $>35 \%$ for cows $>199$ DIM. Also, any cow went on the alert list at any time with milk production $<9 \mathrm{~kg}$. Farm employees classified each cow on the alert list as having no signs of clinical mastitis (no quarter swelling, normal milk) or having what the farm protocol called "coliform mastitis" or "noncoliform mastitis." "Non-coliform" cases were defined by the farm's protocol as having mild to moderate swelling of mammary quarter(s), normal, clotted, or discolored milk but not watery milk, rectal temperature $>39.7^{\circ} \mathrm{C}$, and normal appetite. They were treated i.m. with one of the following 3 commercial products: amoxicillin trihydrate (Amoximast, Pfizer Animal Health), pirlimycin (Pirsue, Pfizer Animal Health), or cephapirin sodium (Today, Fort Dodge Animal Health, Overland Park, KS). During the course of antibiotic therapy, intramammary oxytocin was administered at each milking. "Coliform mastitis" cases were defined by the farm's protocol as having marked swelling of mammary quarter(s) and/or thin or watery milk, and/or rectal temperature $>39.7^{\circ} \mathrm{C}$. (All marked swelling or high temperature or watery milk cases were defined as "coliform" cases). "Coliform" cases were treated with flunixin meglumine (Banamine, Schering-Plough Animal Health, Union, NJ) i.m. and with hypertonic saline i.v. if needed in the judgment of the attending herdsperson. No antibiotic therapy was used for "coliform mastitis" cases with depression or reduced appetite. At the beginning of the dry period, all cows were treated intramammarily with penicillin $\mathrm{G}$ (procaine) and dihydrostreptomycin sulfate (Quartermaster, Pfizer Animal Health). An Escherichia coli J5 bacterin (J-5, Pfizer Animal Health) was administered as labeled to all cows and pregnant nulliparous cows in the herd. During the study, mean milk production per cow was $10,182 \mathrm{~kg} / \mathrm{yr}$, and monthly mean bulk milk SCC was 240,000 cells $/ \mathrm{mL}$ (range 170,000 to 310,000).

\section{Data Collection}

At the initial herd visits, a questionnaire was administered to collect data on mastitis control and other management policies related to udder health in the herd. This included information on cow housing, milking procedures, dry cow and lactating cow therapy, culling practices, milk quality and production data, milking machine maintenance, and performance test results. 
Herd managers and milkers were instructed on aseptic milk sample collection and handling. Written instructions and color code-labeled containers were left at each farm for sample collection. Case definitions were standardized for all 9 diseases (mastitis plus other diseases [see Other Diseases]) recorded in the study and discussed with all farm personnel who were expected to collect data. Milk samples and disease records were picked up from each farm weekly.

To characterize the study herds, we collected a composite sample of milk from each cow for culture at the beginning of the study. The data collection started on October 1, 1999 and ended on July 31, 2001 for Dairy A. Data were collected from October 1, 1999 to March 31, 2001 for Dairy B. Dairy B had less total data collection time because while data collection was begun earlier on Dairy B, some early data were discarded because of technical problems with accurate identification of cows by the milk weight recording system. These problems were corrected by October 1, 1999.

Accuracy of the daily milk weight recording was evaluated on both study farms. For one milking, all cows' identities were verified, and their corresponding milk weights were recorded manually from the parlor display. These were compared with data for each cow in the on-farm computer following the milking. In the computer data, 97\% of all cows' milk weights were recorded correctly.

\section{Case Definition}

All lactating cows in the 2 study herds were eligible for inclusion as cases of clinical mastitis. Clinical mastitis was defined by clinical signs or other criteria as described earlier for each farm. Aseptic quarter milk samples for microbiological culture were collected at clinical onset during every episode of clinical mastitis that occurred during the study period. In this analysis, only the first case of clinical mastitis (regardless of etiology) during the most recently begun lactation was studied. The most recent lactation was used because that was the lactation for which complete daily milk weights could be retrieved. Data from cows contracting clinical mastitis that were subsequently culled or died were included in the study; their records were used up until the time when they left the herd. No projections of further losses were made for such cows; they contributed data only until leaving the herd.

Microbiological procedures used were standard methods (Sears et al., 1993; Hogan et al., 1999); in this report, milk culture results were used only to provide herd descriptive data, which are reported later. To clarify for the readers, the effects of specific etiologic agents of clinical mastitis on milk loss were studied from these data and reported elsewhere (Gröhn et al., 2004). However, in that study there were more cases included because the first episode of clinical mastitis caused by each etiologic agent of interest was studied, i.e., some cows contributed more than one case. Another report from these data examining risk factors for clinical mastitis used the most complete lactation from each cow during the study period because daily milk weight records were not needed for that analysis (González et al., unpublished). Therefore, some of the cases of mastitis reported in this study are the same as in the risk factor study, and some are not (i.e., cases occurring during a complete lactation that ended before a subsequent calving late in the study period are in the risk factor study).

\section{Other Diseases}

Although focusing on clinical mastitis, we chose 8 other diseases for inclusion in the models as potential confounders. These 8 diseases are common and important diseases of dairy cows, often cause milk production loss, have a reasonable basis for influencing replacement decisions, and occur at least in part as a consequence of management decisions. The objective of this was to evaluate the true production loss associated with each of these diseases, accounting for the influence of the others. It also allows for a more precise estimate of the production loss for cows affected by any combination of 2 or more of the diseases.

The 8 recorded diseases (in addition to clinical mastitis) were dystocia, milk fever, retained placenta, metritis, ketosis, displaced abomasum, lameness, and cystic ovarian disease. They are defined as follows. Dystocia is a calving requiring producer or veterinary assistance. Milk fever occurs if a cow is unable to rise or has cool extremities and sluggish rumen motility near the time of calving, but is treated successfully with calcium. Retained placenta is retention of fetal membranes for at least $24 \mathrm{~h}$ post-calving. Metritis involves a febrile state accompanying a purulent or fetid vaginal discharge or a diagnosis of an enlarged uterus by veterinary palpation. Ketosis is diagnosed by a drop in feed intake and milk production; detection of ketones in milk, urine, or breath; no other concomitant diseases; and response to treatment (i.v. dextrose and/or propylene glycol P.O.). Displaced abomasum is a condition in which the abomasum is enlarged with fluid, gas, or both and is mechanically trapped in either the left or right side of the abdominal cavity. Nearly every displaced abomasum case was confirmed by surgery, but cows removed from the herd without treatment were also recorded. Lameness is defined as limping or abnormal weight bearing. An ovarian cyst is defined as a persistent ovarian structure 25 
$\mathrm{mm}$ in diameter and associated with anestrus or erratic estrous behavior. Written disease definitions were provided to all farm personnel and veterinarians collaborating on the project, and effort was made to standardize disease detection on the study farms.

\section{Statistical Methods}

We used a repeated measures technique to estimate the loss of milk production caused by clinical episodes of mastitis. Our database included records of clinical mastitis cases, daily milk yields for all cows in the 2 herds, dystocia, milk fever, retained placenta, metritis, ketosis, displaced abomasum, lameness, cystic ovarian disease, lactation number, month of lactation, and calving season. Milk production data were collected for each milking. A daily milk weight was obtained by adding together the 3 individual milk weights for each day. After that, a weekly average was obtained for each week in lactation by adding together the 7 milk weights and dividing by 7 . This was done to prevent extreme variation caused by a single missing milk weight and also because the exact date of disease diagnosis depends in part on the attentiveness of the individual milker. The regression model was defined by

$$
\begin{gathered}
\mathrm{Y}=\text { herd + calving season + week in milk } \\
\text { + lactation + mastitis + metritis } \\
\text { + displaced abomasum + ketosis + lameness } \\
\text { + cystic ovarian disease + dystocia } \\
\text { + retained placenta + milk fever }+e
\end{gathered}
$$

where $\mathrm{Y}$ is the mean daily milk production averaged by week, during a specific week of lactation of a particular cow that had calved in a particular season in a specific herd. Separate models were used for first lactation animals because the shape of their lactation curve is very different. A parity indicator was used to classify lactation numbers 2,3 , and $\geq 4$ in the model for older cows. The mastitis term represents a set of covariates (categorical variables for time intervals before or after clinical mastitis) modeling the time relative to the first case of mastitis in a given lactation. Separate indicator variables were created for 4 separate wk before the mastitis case, 10 separate wk after the mastitis case, and then one additional for the total lactation thereafter and one for the total lactation before. Cows without mastitis were coded as zero in all of these covariates (indicator variables). Some cows had mastitis in early lactation and were not yet milking at least $4 \mathrm{wk}$ before disease onset. These cows were coded as 0 in the indicator variables for those weeks before disease during which they were still dry. The 5 diseases other than mastitis that could occur throughout lactation (metri- tis, displaced abomasum, ketosis, lameness, and cystic ovarian disease) were coded identically with an indicator variable for the period before diagnosis, 1 and 2 wk after diagnosis, and the period thereafter. Because dystocia, retained placenta, and milk fever only occur at the very beginning of lactation, they were assigned indicator variables for only the period after diagnosis. Finally, $e$ is a complex error term, containing a matrix $R$ for within-cow correlation of subsequent milk weights. Several error structures were evaluated including simple (no correlation), compound symmetry, banded diagonal, autoregressive, and unstructured (estimating a correlation for each separate correlation). A final residual error term was assumed to be identically independently distributed according to a Normal distribution with mean 0 and variance $\sigma^{2}$. The different correlation structures were evaluated using goodness of fit measures. The goodness of fit measures included $-2 * \log$ likelihood (-2LL), Akaike's information criterion (AIC), and Bayesian information criterion (BIC). All fixed effect covariates were evaluated and included in the model when statistically significant. Residuals were evaluated graphically and graphed against predicted value, calendar time, and weeks in milk.

All analyses were performed in SAS, version 8.2, on the Cornell Supercomputer because they were computationally intensive and involved a large number of observations. Statistical significance was defined at $P$ $<0.05$. Each explanatory disease variable included in the final -2LL model was evaluated to see whether the difference in -2LL between the full and reduced models was significant at $P<0.05$.

\section{RESULTS}

The incidence of first occurrence of clinical mastitis (percentage of cows calving during the study with at least one case of clinical mastitis) during lactation was $19.6 \%$ in first lactation cows and $28.8 \%$ in second-plus lactation cows for Dairy A and 6.3\% in first lactation cows and $13.8 \%$ in second-plus lactation cows for Dairy B. Both dairies had relatively good control of subclinical mastitis at the start of the study. The infection status of all cows at the beginning of the study is shown in Table 1. Most cows were culture-negative for mastitis bacteria. The most common pathogen isolated at the beginning of the study was coagulase-negative staphylococci (CNS) (Table 1). Most of the cases of clinical mastitis during the study were caused by environmental pathogens, in an analysis of specific agents (Gröhn et al., unpublished). The distribution of clinical cases of mastitis during lactation is shown in Figure 1. The top panel of Figure 1 shows the distribution for the first lactation cows, and the bottom panel shows this 
Table 1. Cow intramammary infection status in the 2 dairies at the start of the study. All lactating cows in the herds were sampled using a composite sample.

\begin{tabular}{|c|c|c|c|c|}
\hline \multirow[b]{2}{*}{ Microorganism } & \multicolumn{2}{|c|}{ Dairy A } & \multicolumn{2}{|c|}{ Dairy B } \\
\hline & Cows (no.) & $\%$ & Cows (no.) & $\%$ \\
\hline Escherichia coli & 6 & 1 & 4 & 0.5 \\
\hline Klebsiella spp. & 6 & 1 & 2 & 0.2 \\
\hline Streptococcus non-agalactiae & 36 & 5 & 16 & 2 \\
\hline Staphylococcus aureus & 20 & 3 & 14 & 2 \\
\hline Arcanobacterium pyogenes & 2 & 0.3 & 1 & 0.1 \\
\hline Staph spp. ${ }^{1}$ & 170 & 26 & 66 & 8 \\
\hline Other & 30 & 4 & 5 & 0.6 \\
\hline Culture negative & 420 & 64 & 710 & 87 \\
\hline
\end{tabular}

${ }^{1}$ Such as coagulase-negative staphylococcus.

distribution for the older cows. Many cases of clinical mastitis were detected during the first week of lactation, with fewer detected from the second week onward. The second-plus lactation cows had more cases of clinical mastitis than the first lactation cows (Figure 1).

The lactational incidence of other clinical diseases for each of the study herds is shown in Table 2. There were some differences among parity groups, but the most common diseases found in addition to mastitis were dystocia and ketosis in early lactation and lameness throughout lactation (Table 2).

There were 531 cases of clinical mastitis included in the study (first episodes during lactation), 115 cases in first lactation cows and 416 cases in second-plus lactation cows. The 531 cows with clinical mastitis had a total of 739 cases, a mean of 1.4 per cow. There were 396 of 531 cows $(74.6 \%)$ with only one case of clinical mastitis, and 135 of 531 (25.4\%) with additional cases during lactation. The linear mixed models for explaining variation in daily milk yield relative to nonmastitic herdmates, using several different correlation structures, for second-plus lactation cows are shown in Table 3. When the fit of these models was evaluated using -2LL and AIC, the best fitting model (lowest $-2 \mathrm{LL}$ ) appeared to be the model with an unstructured correlation. The next best fitting model was an autoregressive (1) [AR(1)] model. Using the BIC as a goodness of fit criterion, the AR(1) model showed the best fit to the data (lowest BIC). Because the number of parameters to be estimated in a model with an unstructured correlation pattern is so much larger than in a model with an $\mathrm{AR}(1)$ correlation structure, the latter model was preferred for further analysis (Gröhn et al., 1999). There was a strong correlation between subsequent weekly average milk weight observations over the course of lactation in the same animal, and this correlation weakened with the increase in time difference between observations (Table 4). The various correlation structures used different correlation matrices between different weeks in lactation for the same cow to take this non-independence of observations into account (Table 4). The decaying correlation is best represented by the AR(1) correlation structure. Although it underestimates correlation in the large lags, it fits the observed correlation considerably better when compared with the competing error structures. The final milk production loss estimates caused by clinical mastitis for first lactation cows and second-plus lactation cows, with their standard errors, are shown in Table 5. Similarly, estimated milk production losses associated with other clinical diseases for lactation groups are shown in Table 6. For any combination of diseases, the estimates of
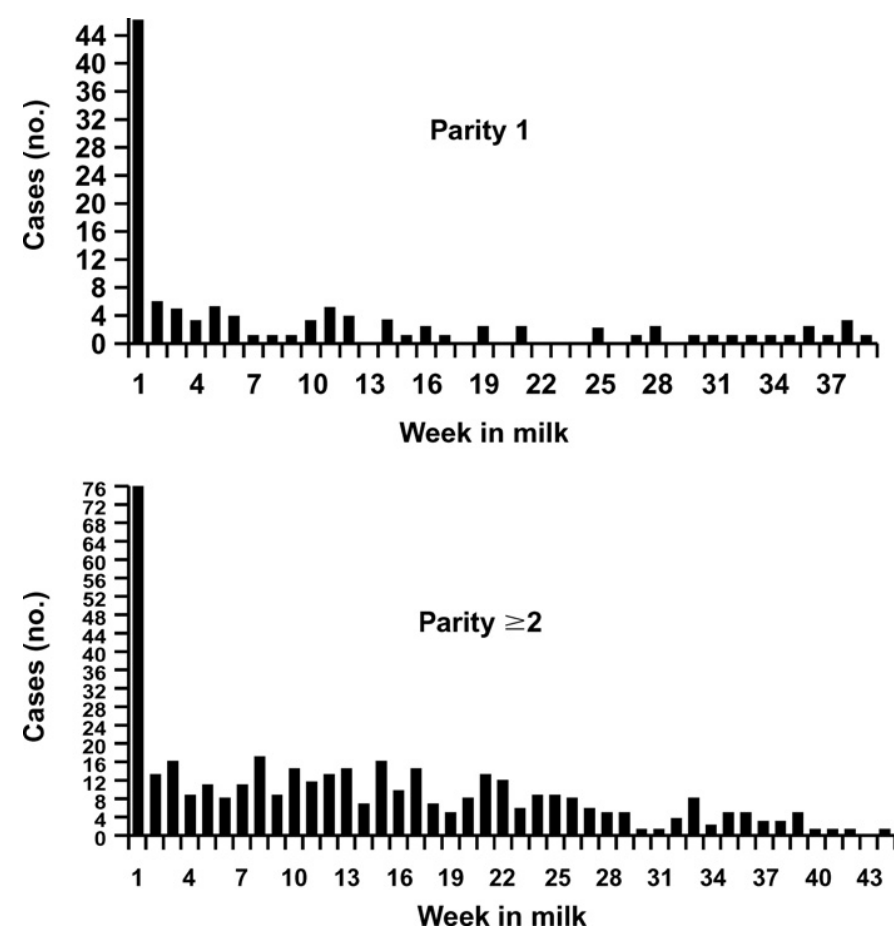

Figure 1. Distribution of DIM at occurrence of all first cases of clinical mastitis. 
Table 2. Lactational incidence of clinical diseases other than clinical mastitis in the study population.

\begin{tabular}{|c|c|c|c|c|c|c|}
\hline \multirow[b]{2}{*}{ Disease } & \multicolumn{3}{|c|}{ Lactation $1(\mathrm{n}=1038)$} & \multicolumn{3}{|c|}{ Lactation $\geq 2(\mathrm{n}=2033)$} \\
\hline & $\begin{array}{l}\text { Cases } \\
\text { (no.) }\end{array}$ & Incidence $(\%)$ & $\begin{array}{l}\text { Median } \\
\text { DIM }\end{array}$ & $\begin{array}{l}\text { Cases } \\
\text { (no.) }\end{array}$ & Incidence $(\%)$ & $\begin{array}{l}\text { Median } \\
\text { DIM }\end{array}$ \\
\hline Dystocia & 317 & 30.5 & 1 & 244 & 12.0 & 1 \\
\hline Milk fever & 0 & 0 & - & 106 & 5.2 & 1 \\
\hline $\begin{array}{l}\text { Retained } \\
\text { placenta }\end{array}$ & 75 & 7.2 & 1 & 249 & 12.2 & 1 \\
\hline Metritis & 144 & 13.9 & 5 & 89 & 4.4 & 8 \\
\hline Ketosis & 128 & 12.3 & 10 & 256 & 12.6 & 11 \\
\hline $\begin{array}{l}\text { Displaced } \\
\text { abomasum }\end{array}$ & 23 & 2.2 & 17 & 59 & 2.9 & 16 \\
\hline Cystic ovary & 16 & 1.5 & 159 & 62 & 3.0 & 166 \\
\hline Lameness & 345 & 33.2 & 172 & 629 & 30.9 & 165 \\
\hline
\end{tabular}

production losses for the concurrent diseases are added. All disease effects were significant at $P<0.05$. Magnitude of milk loss was greatest with displaced abomasum, and increased production was associated with cows diagnosed with cystic ovarian disease (Table 6). Figure 2 shows the milk production for first lactation cows and second-plus lactation cows contracting mastitis at the median DIM of onset. Milk production can be seen decreasing rapidly at the time of onset of clinical mastitis. The level of milk production for mastitic cows does not return completely to the level of that for healthy herdmates (Figure 2).

Residuals were evaluated using graphical tools and observing several residual plots. Residual analysis did not show any obvious pattern in the residuals as the model corrected very well for the inherent shape of the lactation curve; no pattern in the residuals was apparent across weeks in milk. Similarly, an absence

Table 3. Model fit in regression models with different correlation structures and parameter estimates for milk loss caused by clinical mastitis (all pathogens) in second-plus lactation cows.

\begin{tabular}{|c|c|c|c|c|c|}
\hline $\begin{array}{l}\text { Goodness of fit } \\
\text { parameter }\end{array}$ & $\begin{array}{l}\text { Null } \\
\text { model }\end{array}$ & $\mathrm{CS}^{1}$ & $\mathrm{AR}(1)^{2}$ & Toeplitz (5) & Unstructured \\
\hline-2 Residual $\mathrm{LL}^{3}$ & $342112^{6}$ & 287380 & 265436 & 299874 & 261013 \\
\hline $\mathrm{AIC}^{4}$ & 342114 & 287384 & 265440 & 299884 & 263563 \\
\hline $\mathrm{BIC}^{5}$ & 342122 & 287395 & 265450 & 299912 & 270707 \\
\hline Days relative to & ai & rod & ) $\mathrm{re}$ & non-mastit & erdmates \\
\hline$\geq 29 \mathrm{~d}$ pre & $2.2(0.37)$ & $2.7(0.36)$ & & $2.6(0.21)$ & $2.7(0.39)$ \\
\hline 22 to $28 \mathrm{~d}$ pre & $2.2(0.50)$ & $2.6(0.41)$ & & $2.2(0.49)$ & $2.9(0.43)$ \\
\hline 15 to $21 \mathrm{~d}$ pre & $2.3(0.50)$ & $2.6(0.42)$ & & $2.1(0.48)$ & $2.8(0.43)$ \\
\hline 8 to $14 \mathrm{~d}$ pre & $2.1(0.49)$ & $2.3(0.43)$ & & $1.8(0.48)$ & $2.7(0.43)$ \\
\hline 1 to $7 \mathrm{~d}$ pre & $-1.3(0.49)$ & $-0.4(0.44)$ & & $-1.7(0.48)$ & $-0.4(0.43)$ \\
\hline 0 to $7 \mathrm{~d}$ post & $-9.0(0.44)$ & $-9.5(0.43)$ & & $-9.8(0.41)$ & $-9.1(0.42)$ \\
\hline 8 to $14 \mathrm{~d}$ post & $-5.4(0.48)$ & $-6.5(0.45)$ & & $-6.3(0.48)$ & $-5.6(0.44)$ \\
\hline 15 to $21 \mathrm{~d}$ post & $-3.9(0.49)$ & $-5.4(0.46)$ & & $-4.8(0.49)$ & $-4.5(0.45)$ \\
\hline 22 to 28 d post & $-3.4(0.50)$ & $-4.8(0.48)$ & & $-4.2(0.51)$ & $-4.0(0.46)$ \\
\hline 29 to $35 \mathrm{~d}$ post & $-2.8(0.50)$ & $-4.0(0.49)$ & & $-3.7(0.51)$ & $-3.4(0.46)$ \\
\hline 36 to $42 \mathrm{~d}$ post & $-2.5(0.51)$ & $-3.6(0.50)$ & & $-3.2(0.53)$ & $-3.2(0.47)$ \\
\hline 43 to $49 \mathrm{~d}$ post & $-1.8(0.52)$ & $-2.8(0.51)$ & & $-2.2(0.55)$ & $-2.8(0.48)$ \\
\hline 50 to $56 \mathrm{~d}$ post & $-2.0(0.53)$ & $-2.6(0.50)$ & & $-2.2(0.55)$ & $-2.6(0.48)$ \\
\hline 57 to $63 \mathrm{~d}$ post & $-2.1(0.53)$ & $-2.3(0.49)$ & & $-2.2(0.55)$ & $-2.6(0.48)$ \\
\hline 64 to $70 \mathrm{~d}$ post & $-2.6(0.54)$ & $-2.6(0.47)$ & & $-2.6(0.56)$ & $-3.0(0.48)$ \\
\hline$\geq 71 \mathrm{~d}$ post & $-1.3(0.38)$ & $-1.9(0.41)$ & & $-1.4(0.23)$ & $-2.3(0.44)$ \\
\hline
\end{tabular}

${ }^{1}$ Compound symmetry.

${ }^{2}$ Autoregressive (1).

${ }^{3}$ Log likelihood.

${ }^{4}$ Akaike's Information Criterion.

${ }^{5}$ Bayesian Information Criterion.

${ }^{6}$ Goodness of fit statistic; closer to zero indicates better model fit. 
Table 4. Correlation between residuals of subsequent weekly average milk weights in the different regression models. The observed correlation in the residuals and the correlation used in the regression model are shown for each correlation type.

\begin{tabular}{|c|c|c|c|c|c|c|c|c|}
\hline \multirow[b]{2}{*}{$\mathrm{Lag}^{1}$} & \multicolumn{2}{|c|}{ Null model } & \multicolumn{2}{|c|}{$\mathrm{CS}^{2}$} & \multicolumn{2}{|c|}{$\mathrm{AR}(1)^{3}$} & \multicolumn{2}{|c|}{ Toeplitz (5) } \\
\hline & $\mathrm{Obs}^{4}$ & Model $^{5}$ & Obs & Model $^{6}$ & Obs & Model $^{7}$ & Obs & Model $^{8}$ \\
\hline 1 & 0.83 & 0 & 0.84 & 0.51 & 0.83 & 0.82 & 0.83 & 0.17 \\
\hline 2 & 0.72 & 0 & 0.73 & 0.51 & 0.72 & 0.67 & 0.72 & 0.16 \\
\hline 3 & 0.64 & 0 & 0.65 & 0.51 & 0.64 & 0.55 & 0.64 & 0.15 \\
\hline 4 & 0.57 & 0 & 0.58 & 0.51 & 0.58 & 0.45 & 0.58 & 0.14 \\
\hline 5 & 0.52 & 0 & 0.53 & 0.51 & 0.52 & 0.37 & 0.52 & 0 \\
\hline 10 & 0.30 & 0 & 0.33 & 0.51 & 0.33 & 0.14 & 0.32 & 0 \\
\hline 20 & 0.14 & 0 & 0.15 & 0.51 & 0.14 & 0.02 & 0.14 & 0 \\
\hline 30 & 0.05 & 0 & 0.05 & 0.51 & 0.05 & 0.003 & 0.05 & 0 \\
\hline 40 & 0.02 & 0 & 0.02 & 0.51 & 0.02 & 0.0004 & 0.02 & 0 \\
\hline
\end{tabular}

${ }^{1}$ Rows in the table represent consecutive weeks in lactation, e.g., Lag 1 represents milk weights that are 1 wk apart, Lag 2 represents milk weights that are 2 wk apart etc.

${ }^{2}$ Compound symmetry.

${ }^{3}$ Autoregressive (1)

${ }^{4}$ Observed correlation between milk weights from the same cow during different weeks of lactation.

${ }^{5} \mathrm{Null}$ model assumes no correlation between milk weights from different weeks of lactation.

${ }^{6} \mathrm{CS}$ model assumes same correlation $(0.51)$ between milk weights for all weeks of lactation.

${ }^{7} \mathrm{AR}$ (1) model assumes a decay in correlation with $\mathrm{r}_{\mathrm{i}-\mathrm{j}}=\mathrm{r}^{(\mathrm{i}-\mathrm{j})}$, where $\mathrm{i}$ and $\mathrm{j}$ are the week of observation.

${ }^{8}$ Toeplitz model correlations are only calculated for observations up to 4 lags away from the current observation.

of any pattern was observed when plotting residuals against expected values and calendar time. There was no spread in residual values as the predicted value of the observation increased (i.e., there is no obvious heteroscedascity in these data).

Using the AR(1) model (Tables 3 and 5), total milk production loss per average case of clinical mastitis (onset at $81 \mathrm{DIM}$ ) can be calculated by multiplying each weekly estimate of daily milk loss by 7 and adding all estimates over the total lactation. The final daily loss estimate of $1.9 \mathrm{~kg}$ is multiplied by the $153 \mathrm{~d}$ left between $71 \mathrm{~d}$ post onset (152 DIM) and the end of a 305-d lactation. Loss because of mastitis during the whole lactation is then estimated as approximately $598 \mathrm{~kg}$. Assuming that mastitic cows (second-plus lactation) would have had a potential daily advantage of $2.6 \mathrm{~kg}$ over their herdmates throughout the entire lactation if they had never contracted mastitis, the total loss compared with

Table 5. Daily milk production estimates $(\mathrm{kg})$ from the final regression model for mean weekly milk yield in weeks relative to clinical mastitis occurrence by lactation group. The best fitting regression model used an autoregressive, autocorrelation structure. The models also contained effects for herd, calving season, week in lactation, and other diseases.

\begin{tabular}{|c|c|c|c|c|}
\hline \multirow[b]{2}{*}{ Time relative to mastitis } & \multicolumn{2}{|c|}{ Lactation $1(\mathrm{n}=1028)$} & \multicolumn{2}{|c|}{ Lactation $2+(\mathrm{n}=2004)$} \\
\hline & Parameter & $\mathrm{SE}$ & Parameter & SE \\
\hline Intercept & 24.63 & 0.71 & 22.01 & 0.67 \\
\hline$\geq 29 \mathrm{~d}$ pre & 0.37 & 0.56 & 2.70 & 0.36 \\
\hline 22 to $28 \mathrm{~d}$ pre & 0.14 & 0.64 & 2.61 & 0.41 \\
\hline 15 to $21 \mathrm{~d}$ pre & 0.85 & 0.67 & 2.56 & 0.43 \\
\hline 8 to $14 \mathrm{~d}$ pre & 0.40 & 0.66 & 2.32 & 0.43 \\
\hline 1 to $7 \mathrm{~d}$ pre & -1.35 & 0.65 & -0.43 & 0.44 \\
\hline 0 to $7 \mathrm{~d}$ post & -6.69 & 0.59 & -9.45 & 0.43 \\
\hline 8 to $14 \mathrm{~d}$ post & -5.39 & 0.60 & -6.52 & 0.45 \\
\hline 15 to $21 \mathrm{~d}$ post & -5.16 & 0.62 & -5.38 & 0.46 \\
\hline 22 to $28 \mathrm{~d}$ post & -4.41 & 0.63 & -4.75 & 0.48 \\
\hline 29 to $35 \mathrm{~d}$ post & -3.75 & 0.65 & -4.03 & 0.49 \\
\hline 36 to $42 \mathrm{~d}$ post & -4.26 & 0.65 & -3.60 & 0.50 \\
\hline 43 to $49 \mathrm{~d}$ post & -3.52 & 0.65 & -2.81 & 0.51 \\
\hline 50 to $56 \mathrm{~d}$ post & -2.51 & 0.65 & -2.56 & 0.50 \\
\hline 57 to $63 \mathrm{~d}$ post & -2.40 & 0.63 & -2.34 & 0.49 \\
\hline 64 to $70 \mathrm{~d}$ post & -1.52 & 0.59 & -2.62 & 0.47 \\
\hline$\geq 71 \mathrm{~d}$ post & -1.95 & 0.50 & -1.89 & 0.41 \\
\hline
\end{tabular}


Table 6. Daily milk production estimates $(\mathrm{kg})$ from the final regression model for mean weekly milk yield in weeks relative to occurrence of several diseases by lactation group. The best fitting regression model used an autoregressive, autocorrelation structure. The models also contained effects for herd, calving season, week in lactation, and clinical mastitis.

\begin{tabular}{|c|c|c|c|c|c|c|c|c|c|c|c|c|c|c|c|c|}
\hline & \multicolumn{16}{|c|}{ Time relative to disease } \\
\hline & \multicolumn{2}{|c|}{$\geq 15 \mathrm{~d}$ pre } & \multicolumn{2}{|c|}{8 to $14 \mathrm{~d}$ pre } & \multicolumn{2}{|c|}{1 to $7 \mathrm{~d}$ pre } & \multicolumn{2}{|c|}{0 to $7 \mathrm{~d}$ post } & \multicolumn{2}{|c|}{8 to $14 \mathrm{~d}$ post } & \multicolumn{2}{|c|}{15 to 21 post } & \multicolumn{2}{|c|}{22 to $28 \mathrm{~d}$ post } & \multicolumn{2}{|c|}{$\geq 29 \mathrm{~d}$ post } \\
\hline & Est & $\mathrm{SE}$ & Est & $\mathrm{SE}$ & Est & $\mathrm{SE}$ & Est & $\mathrm{SE}$ & Est & $\mathrm{SE}$ & Est & $\mathrm{SE}$ & Est & $\mathrm{SE}$ & Est & $\mathrm{SE}$ \\
\hline \multicolumn{17}{|l|}{ Lactation 1} \\
\hline Dystocia & $-^{1}$ & - & - & - & - & - & -0.21 & 0.41 & -0.26 & 0.39 & -0.13 & 0.37 & -0.05 & 0.33 & 0.46 & 0.25 \\
\hline $\begin{array}{l}\text { Retained } \\
\text { placenta }\end{array}$ & - & - & - & - & - & - & -3.09 & 0.70 & -2.90 & 0.67 & -2.66 & 0.64 & -1.06 & 0.56 & -0.20 & 0.42 \\
\hline Milk fever & - & - & - & - & - & - & $\mathrm{NA}^{2}$ & NA & NA & NA & NA & NA & NA & NA & NA & NA \\
\hline Metritis & -0.29 & 2.12 & -0.48 & 1.19 & -0.28 & 0.63 & -1.25 & 0.52 & -0.71 & 0.52 & -0.27 & 0.50 & 0.06 & 0.46 & 0.39 & 0.38 \\
\hline $\begin{array}{l}\text { Displaced } \\
\text { abomasum }\end{array}$ & 0.33 & 1.88 & 0.17 & 1.48 & -4.06 & 1.32 & -7.29 & 1.25 & -5.37 & 1.32 & -4.65 & 1.30 & -2.42 & 1.18 & -1.96 & 0.92 \\
\hline Ketosis & 2.52 & 1.24 & 3.53 & 0.79 & 2.46 & 0.60 & 0.34 & 0.57 & -0.39 & 0.56 & 0.78 & 0.53 & 1.19 & 0.48 & 1.32 & 0.39 \\
\hline Cystic ovary & 1.27 & 0.91 & 1.96 & 1.15 & 3.37 & 1.27 & 1.89 & 1.37 & 2.60 & 1.41 & 3.45 & 1.42 & 3.50 & 1.38 & 2.70 & 1.21 \\
\hline Lameness & 1.90 & 0.29 & 0.74 & 0.32 & 0.54 & 0.34 & -0.26 & 0.36 & -0.06 & 0.37 & -0.19 & 0.37 & -0.32 & 0.37 & -0.42 & 0.36 \\
\hline \multicolumn{17}{|l|}{ Lactation $2+$} \\
\hline Dystocia & - & - & - & - & - & - & -1.11 & 0.57 & -1.97 & 0.55 & -2.59 & 0.53 & -2.11 & 0.47 & -1.73 & 0.34 \\
\hline $\begin{array}{l}\text { Retained } \\
\text { placenta }\end{array}$ & - & - & - & - & - & - & -4.94 & 0.56 & -5.51 & 0.54 & -4.29 & 0.51 & -2.63 & 0.46 & -1.45 & 0.35 \\
\hline Milk fever & - & - & - & - & - & - & -2.45 & 0.80 & -0.87 & 0.77 & 0.36 & 0.71 & -0.35 & 0.71 & 0.39 & 0.55 \\
\hline Metritis & 0.12 & 2.76 & -0.02 & 1.39 & -1.18 & 0.93 & -2.79 & 0.86 & -1.72 & 0.86 & -1.24 & 0.84 & -0.39 & 0.77 & 0.31 & 0.62 \\
\hline $\begin{array}{l}\text { Displaced } \\
\text { abomasum }\end{array}$ & -1.36 & 1.42 & 0.10 & 1.20 & -4.95 & 1.09 & -12.41 & 1.05 & -10.04 & 1.07 & -8.25 & 1.06 & -4.64 & 0.99 & -3.24 & 0.79 \\
\hline Ketosis & 4.74 & 1.15 & 3.24 & 0.71 & 1.49 & 0.58 & -2.52 & 0.55 & -1.91 & 0.54 & 1.06 & 0.51 & 0.17 & 0.47 & 1.14 & 0.37 \\
\hline Cystic ovary & 1.97 & 0.65 & 2.34 & 0.86 & 2.73 & 0.94 & 2.87 & 0.97 & 2.43 & 1.00 & 0.10 & 1.00 & 0.49 & 0.95 & 0.79 & 0.83 \\
\hline Lameness & 2.18 & 0.27 & 1.68 & 0.31 & 0.37 & 0.33 & -0.89 & 0.34 & -0.47 & 0.35 & -1.02 & 0.35 & -0.69 & 0.35 & -0.60 & 0.33 \\
\hline
\end{tabular}

${ }^{1}$ Not estimated; no milk yields for this time period are available because disease only occurs at beginning of lactation.

${ }^{2}$ Not applicable; no first lactation cows had milk fever. 

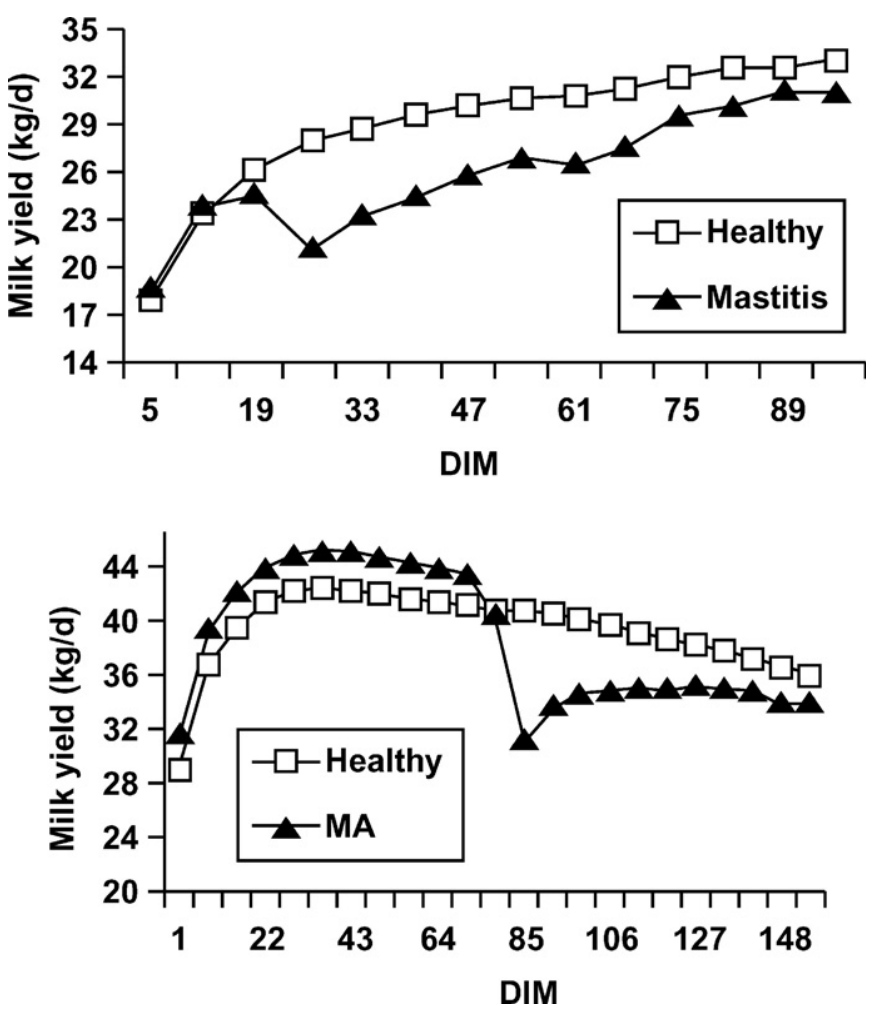

Figure 2. Milk production loss at median days of onset because of clinical mastitis. Top: milk production loss in first lactation cows; median day of mastitis is 22 DIM. Bottom: milk production loss in second-plus lactation cows; median day of mastitis is 81 DIM.

their potential is then approximately $1180 \mathrm{~kg}$. This assumes that there were about $224 \mathrm{~d}$ more of lactation following the onset of clinical mastitis at 81 DIM. Mastitic second-plus lactation cows should have had a production advantage for the remaining lactation over herdmates of $583 \mathrm{~kg}(224 \mathrm{~d} \times 2.6 \mathrm{~kg} / \mathrm{d})$. However, after onset of clinical mastitis, they instead lost $598 \mathrm{~kg}$ as estimated previously. Thus, their total milk production loss estimate was $1181 \mathrm{~kg}(583+598 \mathrm{~kg})$.

Similarly, for first lactation cows, using the AR(1) model estimates in Table 5, the estimated milk production loss throughout lactation following clinical mastitis was $690 \mathrm{~kg}$. First lactation animals contracting mastitis did not have a significant production advantage over herdmates before they contracted mastitis.

\section{DISCUSSION}

As expected, clinical mastitis resulted in a milk production loss shortly before and immediately after diagnosis. Our estimated production loss from mastitis throughout lactation of approximately $600 \mathrm{~kg}$ is in general agreement with previous estimates of $341 \mathrm{~kg}$ in the first $60 \mathrm{~d}$ after the clinical case (Bartlett et al., 1991).
A major difference in our current repeated measures analysis is that we estimated production losses through the remainder of lactation and accounted for the concurrent effects of 8 other diseases. A convenient feature of our model estimates is that for any combination of the 8 diseases, production loss estimates are summed. It is a weakness of the study that subsequent cases of mastitis during the same lactation were not analyzed separately because of practical and financial limitations of Supercomputer use.

Several other studies also observed that clinical mastitis has a detrimental effect on milk production (CoboAbreu et al., 1979; Lucey and Rowlands, 1984; Lucey et al., 1986; Bartlett et al., 1991; Hoblet et al., 1991; Houben et al., 1993; Miller et al., 1993). The effect of clinical mastitis on the degree of milk loss varies depending on the stage of lactation when the disease occurred (Lucey and Rowlands, 1984). Much previous research on the effect of diseases on milk production has focused on the entire 305-d lactation curve. The 305-d milk production estimated from monthly tests usually does not capture short-term fluctuations and drops in milk production. Results have even indicated increased milk production associated with clinical mastitis (Dohoo and Martin, 1984). Cows with mastitis were often the higher producing cows before contracting the disease, and, thus, they produced more, even after having contracted the disease, than their healthy, lower producing herdmates (Gröhn et al., 1995). We also observed that second-plus lactation cows that eventually contracted a case of clinical mastitis out-produced their herdmates by approximately $2.6 \mathrm{~kg} / \mathrm{d}$ before the onset of disease. In our study, when accounting for production loss relative to this higher potential, the true milk loss following clinical mastitis was nearly $1200 \mathrm{~kg}$ for second-plus lactation cows.

The authors realized that using producer-detected clinical mastitis carries some inherent weaknesses with it. Diagnosis certainly depends on the ability and willingness of the farm personnel to examine cows for abnormal milk and other clinical signs of mastitis. In our data, clinical mastitis detection was somewhat different between farms, although both farms used conductivity meters to signal cows with abnormal conductivity, a method that has potentially high sensitivity with somewhat lower specificity (Nielen et al., 1995). Lam et al. (1993) found that producers' observations of mastitis together with severity of clinical signs was not a source of bias and could therefore be used in epidemiologic studies of well-managed herds. In the analysis, it appeared that the effect of clinical mastitis on milk production was remarkably similar between herds.

The methodology used to measure milk loss caused by disease has evolved over time. A mixed model for 
repeated measurements is currently the most sophisticated and accurate statistical technique available to measure milk loss caused by disease. It is ideal because it utilizes repeated (e.g., daily) measurements of milk production. This method allows estimation of milk losses before diagnosis of clinical mastitis as well as afterward. In addition, the estimation is not limited to a certain time period after mastitis; its effect can be determined at any time during lactation. The relatively large amount of data that was available for this analysis (approximately 2,000,000 cow milkings) allowed a rather precise estimation of parameters for the linear mixed model. First, data were summed per day and then averaged per week to reduce the impact of measurement error and daily variation. In a few events, a cow was not recognized in the milking parlor, and her milk weight was set to zero. We did not attempt to correct for this in contrast to rather elaborate efforts by (Deluyker et al., 1991). Because it concerned a small number of data points and because it essentially occurred randomly with regard to mastitis occurrence, no bias was expected from this. The advantage is that true zero milk weights (when the cow was not milked because of mastitis) are fully incorporated into the analysis.

Milk weights of the same cow in the same lactation are necessarily correlated (Gröhn et al., 1999). They can be described by a mathematical model and are therefore more or less predictable from one measure to another (Sherchand et al., 1995). The best fitting correlation pattern was evaluated by looking at -2LL, AIC, and BIC. Ignoring correlation (null model) was used as a 'negative control,' and unspecified (unstructured) correlation, estimating all possible correlations separately, was used as a 'positive control.' These two extremes showed the worst and best fit, respectively, when evaluated by -2LL. However, because of the high number of parameters included in an unstructured correlation model, with its cost in degrees of freedom, the autoregressive $[A R(1)]$ error structure was preferable, even over the unspecified (unstructured) correlation structure. Because only one parameter needs to be estimated in the AR(1) model, the savings in degrees of freedom makes it a very attractive option for modeling longitudinally correlated data. Stanton et al. (1992) also showed for test-day models that an autoregressive structure is the preferred within-lactation correlation pattern. Although a large residual error remains (error variance $=71 \mathrm{~kg}$ ), the model fitting did meet assumptions inherent in linear mixed models.

\section{CONCLUSIONS}

Clinical mastitis is a major production loss disease of dairy cattle. This is compounded by the fact that for cows in second and greater lactation, the disease tends to strike animals producing more milk than their herdmates. Using daily milk production records and repeated measures analysis with AR(1) correlation structure, the effects of dystocia, milk fever, retained placenta, metritis, ketosis, displaced abomasum, lameness, and cystic ovarian disease were all found to significantly affect milk production and were all adjusted for in the estimates of milk lost with each disease. Losses were also compared with the higher production potential of older cows that contracted clinical mastitis. Final models estimated milk production losses for the rest of lactation following clinical mastitis at nearly 700 $\mathrm{kg}$ for first lactation cows and $1200 \mathrm{~kg}$ for second-plus lactation cows.

\section{ACKNOWLEDGMENTS}

The USDA Award No. 98-5204-6489 provided funding for this study. The research was conducted using the resources of the Cornell Theory Center, which receives funding from Cornell University, New York State, federal agencies, and corporate partners. The authors thank owners and personnel from Dairies A and B and the personnel of the Geneseo, Ithaca, and Canton Regional Laboratories, Quality Milk Production Services for their valuable cooperation during the study.

\section{REFERENCES}

Allore, H. G., and H. N. Erb. 1998. Partial budget of the discounted annual benefit of mastitis control strategies. J. Dairy Sci. 81:2280-2292.

Bartlett, P. C., G. Y. Miller, C. R. Anderson, and J. H. Kirk. 1990. Milk production and somatic cell count in Michigan dairy herds. J. Dairy Sci. 73:2794-2800.

Bartlett, P. C., J. Van-Wijk, D. J. Wilson, and C. D. Green. 1991. Temporal patterns of lost milk production following clinical mastitis in a large Michigan Holstein herd. J. Dairy Sci. 74:1561-1572.

Bramley, A. 1990. Environmental mastitis. Pages 158-170 in Am. Assoc. Bovine Pract./Natl. Mastitis Counc. Mtg. Proc., Indianapolis, IN. Natl. Mastitis Counc., Inc., Arlington, VA.

Bramley, A., and F. Dodd. 1984. Reviews of the progress of dairy science: Mastitis control-Progress and prospects. J. Dairy Res. 51:481-512.

Cobo-Abreu, R., S. W. Martin, R. A. Willoughby, and J. B. Stone. 1979. The association between disease, production and culling in a university dairy herd. Can. Vet. J. 20:191-195.

DeGraves, F. J., and J. Fetrow. 1993. Economics of mastitis and mastitis control. Pages 421-434 In Veterinary Clinics of North America (Food Animal Practice). Vol. 9. K. L. Anderson, ed. W. B. Saunders, Philadelphia, PA.

DeLuyker, H. A., J. M. Gay, L. D. Weaver, and A. S. Azari. 1991. Change of milk yield with clinical diseases for a high producing dairy herd. J. Dairy Sci. 74:436-445.

DeLuyker, H. A., R. H. Shumway, W. E. Wecker, A. S. Azari, and L. D. Weaver. 1990. Modeling daily milk yield in Holstein cows using time series analysis. J. Dairy Sci. 73:539-548.

Detilleux, J. C., Y. T. Gröhn, and R. L. Quaas. 1994. Effects of clinical ketosis on test day milk yields in Finnish Ayrshire cattle. J. Dairy Sci. 77:3316-3323. 
Detilleux, J. C., Y. T. Gröhn, S. W. Eicker, and R. L. Quaas. 1997. Effects of left displaced abomasum on test day milk yields in Holstein cattle. J. Dairy Sci. 80:121-126.

Dhanoa, M. S., and Y. L. P. LeDu. 1982. A partial adjustment model to describe the lactation curve of a dairy cow. Anim. Prod. 34:243-247.

Dohoo, I. R., and S. Martin. 1984. Disease, production and culling in Holstein-Friesian cows III. Disease and production as determinants of disease. Prev. Vet. Med. 2:671-690.

Erskine, R. J., R. J. Eberhart, L. J. Hutchinson, S. B. Spencer, and M. A. Campbell. 1988. Incidence and types of clinical mastitis in dairy herds with high and low somatic cell counts. JAVMA 192:761-765.

González, R. N., D. E. Jasper, N. C. Kronlund, T. B. Farver, J. S. Cullor, R. B. Bushnell, and J. D. Dellinger. 1990. Clinical mastitis in two California dairy herds participating in contagious mastitis control programs. J. Dairy Sci. 73:648-660.

González, R. N., D. J. Wilson, J. A. Hertl, H. F. Schulte, G. J. Bennett, Y. H. Schukken, and Y. T. Gröhn. Occurrence and risk factors for pathogen-specific clinical mastitis in dairy cows. J. Dairy Sci., submitted for publication.

Gröhn, Y. T., S. W. Eicker, and J. A. Hertl. 1995. The association between previous 305-day milk yield and disease in New York State dairy cows. J. Dairy Sci. 78:1693-1702.

Gröhn, Y. T., J. J. McDermott, Y. H. Schukken, J. A. Hertl, and S. W. Eicker. 1999. Analysis of correlated continuous repeated observations: Modelling the effect of ketosis on milk yield in dairy cows. Prev. Vet. Med. 39:137-153.

Gröhn, Y. T., D. J. Wilson, R. N. González, J. A. Hertl, H. F. Schulte, G. J. Bennett, and Y. H. Schukken. 2004. Effect of pathogenspecific clinical mastitis on milk yield in dairy cows. J. Dairy Sci. (accepted)

Hoblet, K. H., G. D. Schnitkey, D. Arbaugh, J. S. Hogan, K. L. Smith, P. S. Schoenberger, D. A. Todhunter, W. D. Hueston, D. E. Pritchard, G. L. Bowman, L. E. Heider, B. L. Brockett, and H. R. Conrad. 1991. Cost associated with selected preventive practices and with episodes of clinical mastitis in nine herds with low somatic cell counts. JAVMA 199:190-196.

Hogan, J. S., R. N. González, R. J. Harmon, S. C. Nickerson, S. P. Oliver, J. W. Pankey, and K. L. Smith. 1999. Laboratory Handbook on Bovine Mastitis. Natl. Mastitis Counc., Inc, Madison, WI.
Hogan, J. S., K. L. Smith, K. H. Hoblet, P. S. Schoenberger, D. A. Todhunter, W. D. Hueston, D. E. Pritchard, G. L. Bowman, L. E. Heider, B. L. Brockett, and H. R. Conrad. 1989. Field survey of clinical mastitis in low somatic cell count herds. J. Dairy Sci. 72:1547-1556.

Houben, E. H. P., A. A. Dijkhuizen, J. A. M. Arendonk, and R. Huirne. 1993. Short- and long-term production losses and repeatability of clinical mastitis in dairy cattle. J. Dairy Sci. 76:2561-2578.

Lam, T. J. G. M., Y. H. Schukken, F. J. Grommers, J. A. H. Smit, and A. Brand. 1993. Within-herd and between-herd variation in diagnosis of clinical mastitis in cattle. JAVMA 202:938-942.

Lucey, S., and G. J. Rowlands. 1983. Relationships between production, disease, and milk yield. Page 85 in Proc. 5th Intl. Conf. Prod. Disease in Farm Animals, Uppsala, Sweden.

Lucey, S., and G. J. Rowlands. 1984. The association between clinical mastitis and milk yield in dairy cows. Anim. Prod. 39:165-175.

Lucey, S., G. J. Rowlands, and A. M. Russell. 1986. Short-term associations between disease and milk yield of dairy cows. J. Dairy Res. 53:7-15.

Miller, G. Y., P. C. Bartlett, S. E. Lance, S. Anderson, and L. E. Heider. 1993. Costs of clinical mastitis and mastitis prevention in dairy herds. JAVMA 202:1230-1236.

Nielen, M., Y. H. Schukken, A. Brand, S. Haring, and R. T. Ferwerdavan Zonneveld. 1995. Comparison of analysis techniques for online detection of clinical mastitis. J. Dairy Sci. 78:1050-1061.

Raubertas, R. F., and G. E. Shook. 1982. Relationships between lactation measures of somatic cell concentration and milk yield. J. Dairy Sci. 65:419-425.

Sears, P. M., R. N. Gonzalez, D. J. Wilson, and H. R. Han. 1993. Procedures for mastitis diagnosis and control. Pages 445-468 in Veterinary Clinics of North America (Food Animal Practice). Vol. 9. K. L. Anderson, ed. W. B. Saunders, Philadelphia, PA.

Sherchand, L., R. W. McNew, D. W. Kellogg, and Z. B. Johnson. 1995. Selection of a mathematical model to generate lactation curves using daily milk yields of Holstein cows. J. Dairy Sci. 78:25072513.

Stanton, T. L., L. R. Jones, R. W. Everett, and S. D. Kachman. 1992 Estimating milk, fat, and protein lactation curves with a test day model. J. Dairy Sci. 75:1691-1700.

Wood, P. D. P. 1967. Algebraic model of the lactation curve in cattle. Nature 216:164-165.

Wood, P. D. P. 1977. The biometry of lactation. J. Agric. Sci. (Camb.) 88:333-339. 